\title{
Efektifitas Pemberian Ekstrak Daun Kelor terhadap Kadar Kolesterol Darah Pada Hewan Coba Mencit
}

\author{
Ayu Ulfiah Azis ${ }^{1 *}$, Arina F Arifin², Rezky Pratiwi L.B³, Sri Wahyuni \\ Gayatri $^{4}$, Nesyana Nurmadilla ${ }^{5}$ \\ ${ }^{1}$ Mahasiswa Program Studi Pendidikan Dokter, Fakultas Kedokteran, Universitas Muslim Indonesia \\ ${ }^{2}$ Dosen Bagian Histologi Fakultas Kedokteran Universitas Muslim Indonesia \\ ${ }^{3}$ Dosen Bagian Histologi Fakultas Kedokteran Universitas Muslim Indonesia \\ ${ }^{4}$ Dosen Bagian Biokimia Fakultas Kedokteran Universitas Muslim Indonesia \\ ${ }^{5}$ Dosen Bagian Gizi Fakultas Kedokteran Universitas Muslim Indonesia \\ *Email Korespondensi: ayuulfiahazis71582@gmail.com Telp: 082332929020
}

\begin{abstract}
ABSTRAK
Latar belakang: Kolesterol adalah metabolit yang mengandung lemak dan berfungsi sebagai prekursor untuk hormon steroid dan garam empedu serta merupakan komponen yang menstabilkan membran plasma. Kolesterol merupakan lemak yang penting, namun jika berlebihan dalam darah dapat membahayakan kesehatan. Di Indonesia penyakit kardivaskular terutama penyakit jantung kororner dan stroke menjadi perhatian karena kematian akibat kedua penyakit ini diperkirakan akan terus meningkat mencapai 23.3 juta pada tahun 2030.Tujuan pada penelitian ini untuk mengetahui pengaruh pemberian ekstrak daun kelor (Moringa Oleifera) dalam menurunkan kadar kolesterol darah pada hewan coba mencit (Mus musculus).

Metode: Metode penelitian ini adalah pre and post test control group design. Subjek dibagi menjadi 4 kelompok yaitu kelompok 1 pemberian aquades sebagai kontrol negatif, kelompok 2 ekstrak daun kelor dosis $20.8 \mathrm{mg} / \mathrm{kgBB}$, kelompok 3 ekstrak daun kelor dosis $41.6 \mathrm{mg} / \mathrm{kgBB}$, dan kelompok 4 pemberian simvastatin sebagai kontrol positif. Jumlah sampel pada penelitian ini adalah 26 sampel mencit dibagi menjadi 4 kelompok.

(Berlanjut halaman selanjutnya)
\end{abstract}

Article history:

Received: 1 May 2020

Accepted: 23 June 2020

Publish Online: 30 June 2020

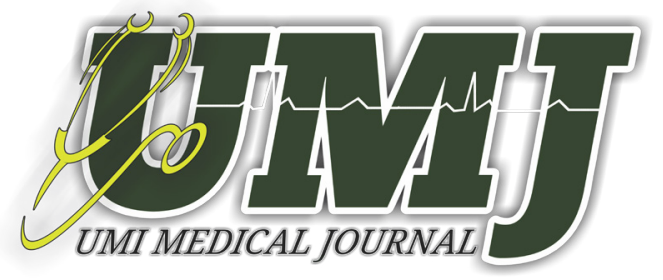

Published By :

Fakultas Kedokteran

Universitas Muslim Indonesia

Phone:

+6282293330302
Address:

Jl. Urip Sumoharjo Km. 5 (Kampus II UMI)

Makassar, Sulawesi Selatan.

Email:

medicaljournal@umi.ac.id 


\title{
(Lanjutan halaman sebelumnya)
}

Hasil: Didapatkan bahwa kelompok perlakuan yang diberi aquades tidak mengalami penurunan kolesterol ( $>0.05)$ sedangkan ekstrak daun kelor dosis 20,8 mg/kgBB mengalami penurunan kolesterol sebesar $15.83 \mathrm{mg} / \mathrm{dl}(\mathrm{p}<0.05)$, ekstrak daun kelor dosis 41,6 mg/kgBB mengalami penurunan kadar kolesterol sebesar $17.83 \mathrm{mg} / \mathrm{dl}(\mathrm{p}<0.05)$, dan kelompok kontrol positif yang diberi suspensi simvastatin mengalami penurunan kadar kolesterol sebesar $19.67 \mathrm{mg} / \mathrm{dl}(\mathrm{p}<0.05)$. Berdasarkan uji anova didapatkan $\mathrm{p}<0.05$, uji post hoc test (LSD) didapatkan simvastatin terhadap dosis $20,8 \mathrm{mg} / \mathrm{KgBB}$ dengan $\mathrm{p}<0.05$, simvastatin terhadap dosis $41.6 \mathrm{mg} / \mathrm{KgBB}$ dengan $\mathrm{p}>0.05$.

Kesimpulan: Pada masing-masing kelompok mencit hiperkolesterolemik yang dilakukan pemberian ekstrak daun kelor dengan dosis yang berbeda didapatkan pengaruh aquades dalam menurunkan kadar kolestrol darah pada hewan coba mencit (Mus musculus) tidak seefektif dengan pemberian simvastatin.

Kata kunci: Kolesterol; moringa oleifera; mus musculus; simvastatin

\begin{abstract}
Background: Cholesterol is a fat-containing metabolite that acts as a precursor for steroid hormones and bile salts and is a component that stabilizes the plasma membrane. Cholesterol is an important fat, but if excessive in the blood can be dangerous to health. In Indonesia, cardiovascular disease, especially coronary heart disease and stroke, is a concern because deaths from these two diseases are expected to continue to reach 23.3 million in 2030. The purpose of this study is to determine the effect of Moringa Oleifera leaf extract in reducing blood cholesterol levels in animals mice (Mus musculus).

Methods: This research method was pre and post test control group design. Subjects were divided into 4 groups, namely group 1 giving aquades as negative control, group 2 Moringa leaf extract dose of $20.8 \mathrm{mg} / \mathrm{kg}$ body weight, group 3 Moringa leaf extract dose $41.6 \mathrm{mg} / \mathrm{kg}$ body weight, and group 4 giving simvastatin as a positive control. The number of samples in this study were 26 samples of mice divided into 4 groups.

Results: It was found that the treatment group given aquades did not experience a decrease in cholesterol $(\mathrm{p}>0.05)$ while Moringa leaf extract dose of $20.8 \mathrm{mg} / \mathrm{kgBW}$ decreased cholesterol by $15.83 \mathrm{mg} / \mathrm{dl}(\mathrm{p}<0.05)$, Moringa leaf extract dose $41.6 \mathrm{mg} / \mathrm{kgBB}$ decreased cholesterol levels by $17.83 \mathrm{mg} / \mathrm{dl}(\mathrm{p}<0.05)$, and the positive control group given simvastatin suspension decreased cholesterol levels by $19.67 \mathrm{mg} / \mathrm{dl}(\mathrm{p}<0.05)$. Based on anova test obtained $\mathrm{p}<0.05$, post hoc test (LSD) obtained simvastatin against a dose of $20.8 \mathrm{mg} / \mathrm{KgBB} \mathrm{p}<0.05$, simvastatin against a dose of $41.6 \mathrm{mg} / \mathrm{KgBB} \mathrm{p}>0.05$.

Conclusion: In each group of hypercholesterolemic mice that carried out administration of Moringa leaf extract with different doses, it was found that the influence of distilled water in reducing blood cholesterol levels in mice (Mus musculus) was not as effective as simvastatin administration.
\end{abstract}

Keywords: Cholesterol; moringa oleifera; mus musculus; simvastatin 


\section{PENDAHULUAN}

Kolesterol adalah metabolit yang mengandung lemak dan berfungsi sebagai prekursor untuk hormon steroid dan garam empedu serta merupakan komponen yang menstabilkan membran plasma. ${ }^{1}$

Kolesterol ditemukan dalam sel darah merah, membran sel dan otot.Tujuh puluh persen kolesterol diesterifikasikan (dikombinasikan dengan asam lemak) dan 30\% dalam bentuk bebas. Kolesterol merupakan lemak yang berwarna kekuningan dan seperti lilin yang diproduksi oleh tubuh terutama di dalam hati. Kolesterol merupakan lemak yang penting, namun jika berlebihan dalam darah dapat membahayakan kesehatan. ${ }^{2,3}$

Kondisi ini merupakan cikal bakal terjadinya Hiperkolesterolemia. Hiperkolesterolemia akan menyebabkan aterosklerosis yang menjadi faktor resiko yang kuat terhadap penyakit kardiovaskular, seperti: penyakit jantung koroner, gagal jantung, hipertensi, infark miokard akut dan stroke. Penyakit kardiovaskular menjadi salah satu penyebab kematian terbesar pada usia produktif. Di Indonesia penyakit kardivaskular terutama penyakit jantung kororner dan stroke menjadi perhatian karena kematian akibat kedua penyakit ini diperkirakan akan terus meningkat mencapai 23,3 juta pada tahun 2030 menurut KEMENKES RI. 2014. Oleh karena itu peneliti tertarik untuk mencoba meneliti daun kelor sebagai tanaman untuk menurunkan kolesterol. Melihat potensi daun kelor di indonesia tumbuh dengan baik, daun kelor juga adalah tanaman yang tidak terlalu sulit untuk di dapatkan ,selain banyak ditanam di depan atau belakang rumah juga sering di komsumsi oleh masyarakat. Di beberapa wilayah di Indonesia, utamanya Indonesia bagian timur kelor di konsumsi sebagai salah satu menu sayuran. ${ }^{4}$

Selain itu Kelor mangandung 539 senyawa yang dikenal dalam pengobatan tradisional Afrika dan India serta telah digunakan dalam pengobatan tradisional untuk mencegah lebih dari 300 penyakit. Berbagai bagian dari tanaman kelor bertindak sebagai stimulan jantung dan peredaran darah, memiliki antitumor, antipiretik, antiepilepsi, antiinflamasi, antiulser, diuretik, antihipertensi, menurunkan kolesterol, antioksidan, antidiabetik, antibakteri dan anti-jamur. ${ }^{4}$

Tidak begitu banyak masyarakat yang tahu manfaat daun kelor secara spesifik. Sebuah hasil penelitian menunjukkan kelor mengandung senyawa aktif yaitu alkaloid dan flavanoid. Kedua senyawa ini di duga efektif menurunkan rasa nyeri akibat rematik, menghambat pembentukan asam urat dan bersifat anti inflamasi serta analgetik. Selain itu, senyawa alkaloid dan flavanoid juga dapat menurunkan kadar kolesterol darah. ${ }^{4}$

Dengan adanya kandungan metabolit sekunder dari buah kelor, mendorong peneliti untuk melakukan penelitian mengenai efek ektrak buah kelor terhadap penurunan kadar kolesterol darah pada mencit.Daun Kelor yang kaya akan nutrisi ini memiliki sifat fungsional karena tanaman ini mempunyai khasiat dan manfaat untuk kesehatan manusia. Baik kandungan nutrisi maupun berbagai zat aktif yang terkandung dalam tanaman ini dapat dimanfaatkan untuk kepentingan mahluk hidup dan lingkungan. ${ }^{5}$

Oleh karena itu kelor mendapat julukan sebagai “miracle tree”. Berbagai penelitian tentang Moringa oleifera Lam pada beberapa tahun terakhir terutama pada tikus. Berdasarkan hasil penelitian in vitro pada hewan dan manusia membuktikan bahwa semua bagian dari Moringa oleifera Lam memiliki fungsi baik secara fisiologis maupun farmakologi. 
Penelitian sebelumnya yang dilakukan pada manusia mengindikasikan bahwa bubuk daun Moringa oleifera Lam yang diberikan secara oral diketahui berguna sebagai anti-hiperglikemia, anti dislipidemia, kemoprotektif, dan efek antioksidan tanpa menimbulkan efek samping. ${ }^{5}$

Analisis kualitatif terhadap ekstrak hidroalkoholik Moringa oleifera Lam membuktikan adanya kandungan sitosterol sebanyak 0,09\%. Kandungan sitosterol ini yang menurunkan kadar kolesterol dengan cara menurunkan konsentrasi LDL (Low Density Lipoprotein) dalam plasma dan menghambat reabsorbsi kolesterol dari sumber endogen. Ekstrak Moringa oleifera Lam juga diketahui mengandung antioksidan flavonoids dan polyphenols. Senyawa ini secara signifikan dapat meningkatkan SOD (Superoxide Dismutase) dan katalase serta menurunkan kadar lipid peroksidase sehingga dapat menurunkan kadar kolesterol terutama LDL. 6,7

\section{METODE}

Penelitian yang dilakukan adalah penelitian eksperimental laboratorik dengan rancangan penelitian pre and post test control group design. Pretest dan Post-test Control Group Design terdapat dua kelas yang dipilih secara langsung, kemudian diberi pre test untuk mengetahui keadaan awal, adakah perbedaan antara kelas eksperimen dan kelas kontrol. Eksperimental design (experimental) merupakan salah satu dari bentuk penelitian eksperimental. Ciri utama dari true experimental adalah sampel yang digunakan untuk eksperimen maupun sebagai kelompok kontrol diambil secara random dari populasi tertentu. Jadi cirinya adalah adanya kelompok kontrol dan sampel yang dipilih secara random. Subjek dibagi menjadi 4 kelompok yaitu kelompok 1 pemberian aquades sebagai kontrol negatif, kelompok 2 ekstrak daun kelor dosis 20,8 mg/kgBB, kelompok 3 ekstrak daun kelor dosis 41,6 mg/kgBB, dan kelompok 4 pemberian simvastatin sebagai kontrol positif.

\section{HASIL}

Untuk menyeleksi sampel yang akan diteliti maka dilakukan pengukuran kadar kolesterol total darah pada mencit. Pada saat mencit baru datang sehingga diperoleh kadar kolesterol total darah pada tiap mencit saat adaptasi diperlihatkan pada tabel dibawah ini:

Tabel 1. Kadar Kolesterol Total Darah Mencit Pada Saat diadaptasikan

\begin{tabular}{ccc}
\hline No & Kelompok Perlakuan & Rerata Kadar Kolesterol Total \\
\hline 1 & Aquades $(-)$ & 114.000 \\
\hline 2 & Simvastatin $(+)$ & 115.833 \\
\hline 3 & Dosis $20,8 \mathrm{mg} / \mathrm{KgBB}$ & 119.500 \\
\hline 4 & Dosis $41,6 \mathrm{mg} / \mathrm{KgBB}$ & 113.167 \\
\hline
\end{tabular}

Dari data yang ada pada tabel 1 dapat dilihat bahwa kadar kolesterol darah total pada saat mencit baru diadaptasikan berada pada kadar hiperkolesterolemik yaitu dengan rata rata; kelompok $1114.000 \mathrm{mg} / \mathrm{dl}$, kelompok 2 dengan rata rata $119.500 \mathrm{mg} / \mathrm{dl}$, kelompok 3 dengan rata rata $113.177 \mathrm{mg} / \mathrm{dl}$, dan kelompok 4 dengan rata-rata $115.833 \mathrm{mg} / \mathrm{dl}$. 
Setelah diadaptasikan maka keempat kelompok itu diberikan pemberian pakan tinggi kolesterol, kadar kolestrol total 4 kelompok mencit yang diberi pakan tinggi kolestrol menunjukkan hiperkolestrolemia $(>82,4$ $\mathrm{mg} / \mathrm{dL}$ ) dan ditetapkan sebagai sampel dalam penelitian ini, dapat dilihat dari table dibawah ini:

Tabel 2. Kadar Kolesterol Total Darah Mencit pada Saat diberikan Pakan Tinggi Lemak

\begin{tabular}{ccc}
\hline No & Kelompok Perlakuan & Rerata Kadar Kolesterol Total \\
\hline 1 & Aquades $(-)$ & 128.833 \\
\hline 2 & Simvastatin $(+)$ & 139.667 \\
\hline 3 & Dosis $20,8 \mathrm{mg} / \mathrm{KgBB}$ & 137.333 \\
\hline 4 & Dosis $41,6 \mathrm{mg} / \mathrm{KgBB}$ & 135.500 \\
\hline
\end{tabular}

Dari data yang ada pada tabel 2 dapat dilihat bahwa kadar kolesterol darah total pada saat diberikan pakan tinggi lemak berada pada kadar hiperkolesterolemik yaitu dengan rata rata kelompok $1128.833 \mathrm{mg} /$ dl , kelompok 2 dengan rata rata $137.333 \mathrm{mg} / \mathrm{dl}$, kelompok 3 dengan rata rata $135.500 \mathrm{mg} / \mathrm{dl}$, dan kelompok 4 dengan rata-rata $139.667 \mathrm{mg} / \mathrm{dl}$.

Sampel kemudian diberi perlakuan berbeda. Kelompok 1 akan diberi Plasebo Aquades, sedangkan kelompok 2 sebagai kelompok uji diberi ekstrak daun kelor dosis 20,8 mg/KgBB, Kelompok 3 sebagai kelompok uji diberi ekstrak daun kelor dosis $41,6 \mathrm{mg} / \mathrm{KgBB}$, dan kelompok 4 sebagai kelompok uji Simvastatin. Perlakuan tersebut dilakukan mulai hari ke-7 hingga hari ke-14, kemudian dilakukan pengukuran kadar kolesterol darah yang hasilnya ditunjukkan pada tabel berikut.

Tabel 3. Kadar Kolesterol Total Darah Mencit setelah Pemberian Perlakuan Keempat Kelompok

\begin{tabular}{ccc}
\hline No & Kelompok Perlakuan & Rerata Kadar Kolesterol Total \\
\hline 1 & Aquades $(-)$ & 130.333 \\
\hline 2 & Simvastatin $(+)$ & 120.000 \\
\hline 3 & Dosis $20,8 \mathrm{mg} / \mathrm{KgBB}$ & 121.500 \\
\hline 4 & Dosis $41,6 \mathrm{mg} / \mathrm{KgBB}$ & 117.667 \\
\hline
\end{tabular}

Dari data yang ada pada tabel 3 dapat dilihat bahwa kadar kolesterol darah total pada saat setelah pemberian perlakuan pada mencit yaitu dengan rata rata kelompok $1130.333 \mathrm{mg} / \mathrm{dl}$, kelompok 2 dengan rata rata $121.500 \mathrm{mg} / \mathrm{dl}$ kelompok 3 dengan rata rata $117.667 \mathrm{mg} / \mathrm{dl}$, dan kelompok 4 dengan rata-rata $120.000 \mathrm{mg} / \mathrm{dl}$.

Terjadi penurunan kadar kolesterol total darah tertinggi pada kelompok 3 dibandingkan dengan 4 kelompok lainnya yakni dengan rerata $117,667 \mathrm{mg} / \mathrm{dl}$ dari pengukuran sebelumnya namun tidak sampai pada kadar kolesterol normal. Data dari ketiga tabel diatas diilustrasikan dalam bentuk gambar dibawah ini: 


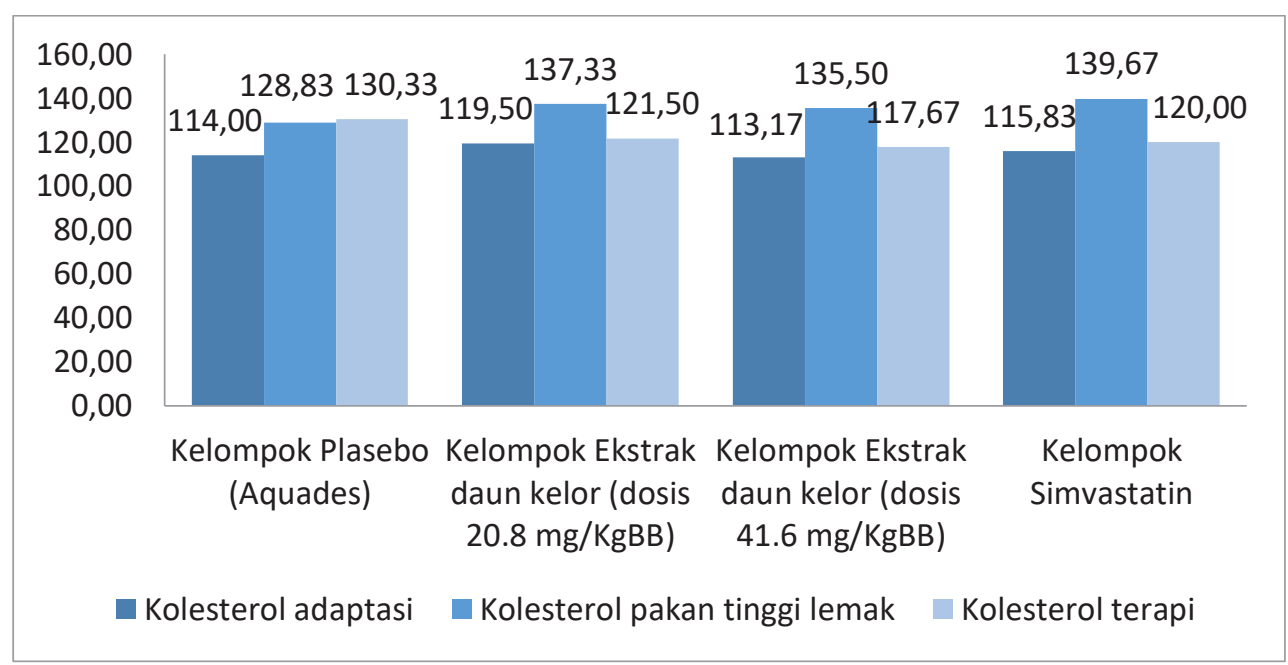

\section{Gambar 1. Perubahan Kadar Kolesterol Darah Total pada Mencit}

Untuk mengetahui data berdistribusi normal atau tidak, maka dilakukan uji normalitas terlebih dahulu. Hasil pengujian dengan metode Shapiro-Wilk (subjek $<50)$ pada tabel 5 dapat dilihat bahwa semua nilai $\mathrm{P}$ dari data yang telah dimasukkan untuk melihat apakah masuk ke nilai signifikansi ( $>0.05)$ atau tidak.

\section{Uji Normalitas Shapiro-Wilk}

\begin{tabular}{ccccc}
\hline & \multirow{2}{*}{ Perlakuan } & \multicolumn{3}{c}{ Shapiro-Wilk } \\
\cline { 3 - 5 } & & Statistic & df & Sig. \\
\hline \multirow{3}{*}{$\begin{array}{c}\text { Penurunan Kadar } \\
\text { Kolesterol Total }\end{array}$} & Aquades (-) & .938 & 6 & .646 \\
\cline { 2 - 5 } & Dosis $20,8 \mathrm{mg} / \mathrm{kgBB}$ & .866 & 6 & .212 \\
\cline { 2 - 5 } & Dosis $41,6 \mathrm{mg} / \mathrm{kgBB}$ & .866 & 6 & .212 \\
\cline { 2 - 5 } & Simvastatin $(+)$ & .823 & 6 & .093 \\
\hline
\end{tabular}

Pada tabel 4 dapat dilihat bahwa semua nilai Sig. dari data yang telah dimasukkan melebihi nilai signifikan ( $>0.05$ ) sehingga dapat disimpulkan bahwa data berdistribusi normal sehingga dapat dilanjutkan untuk pengujian analisis antar varian.

Analisis data dilakukan dengan melakukan perbandingan dari pengukuran kadar kolesterol total darah mencit sebelum pemberian pakan tinggi lemak terhadap kadar kolesterol total darah, setelah pemberian pakan tinggi lemak hingga pemberian perlakuan terapi di ketiga kelompok dari hari ke-1 hingga hari ke-7 dengan menggunakan Uji ANOVA pada tabel berikut ini: 
Tabel 5. Hasil Uji ANOVA Perbandingan Efektifitas pemberian Aquades, Ekstrak daun kelor, dan Simvastatin

\begin{tabular}{cccccc}
\hline & Sum of Squares & Df & Mean Square & F & Sig. \\
\hline Between Groups & 1.716 .458 & 3 & 572.153 & 142.150 & .000 \\
\hline Within Groups & 80.500 & 20 & 4.025 & & \\
\hline Total & 1.796 .958 & 23 & & & \\
\hline
\end{tabular}

Dari tabel 5 dapat dilihat bahwa uji Anova pada tingkat kepercayaan 95\% memberikan harga probabilitas $\mathrm{p}=0,000$, atau $(\mathrm{P}=<0,05)$ berarti ada perbedaan bermakna penurunan kadar kolesterol total pada hewan coba. Untuk mengetahui kelompok mana yang mempunyai perbedaan bermakna, maka dilanjutkan dengan uji LSD.

Tabel 6. Hasil Multiple Comparison ANOVA Uji Lanjut LSD Kelompok Terapi

\begin{tabular}{|c|c|c|c|c|}
\hline (I) Perlakuan & (J) Perlakuan & Mean Difference (I-J) & Std. Error & Sig. \\
\hline \multirow{3}{*}{ Aquades (-) } & $\begin{array}{c}\text { Dosis } 20,8 \mathrm{mg} / \\
\mathrm{kgBB}\end{array}$ & $-17.33333^{*}$ & 115.830 & .000 \\
\hline & $\begin{array}{c}\text { Dosis } 41,6 \mathrm{mg} / \\
\mathrm{kgBB}\end{array}$ & $-19.33333^{*}$ & 115.830 & .000 \\
\hline & Simvastatin $(+)$ & $-21.16667^{*}$ & 115.830 & .000 \\
\hline \multirow{3}{*}{$\begin{array}{c}\text { Dosis } 20,8 \mathrm{mg} / \\
\mathrm{kgBB}\end{array}$} & Aquades (-) & $17.33333^{*}$ & 115.830 & .000 \\
\hline & $\begin{array}{c}\text { Dosis } 41,6 \mathrm{mg} / \\
\mathrm{kgBB}\end{array}$ & -200.000 & 115.830 & .100 \\
\hline & Simvastatin $(+)$ & $-3.83333^{*}$ & 115.830 & .003 \\
\hline \multirow{3}{*}{$\begin{array}{c}\text { Dosis } 41,6 \mathrm{mg} / \\
\mathrm{kgBB}\end{array}$} & Aquades (-) & $19.33333^{*}$ & 115.830 & .000 \\
\hline & $\begin{array}{c}\text { Dosis } 20,8 \mathrm{mg} / \\
\mathrm{kgBB}\end{array}$ & 200.000 & 115.830 & .100 \\
\hline & Simvastatin $(+)$ & -183.333 & 115.830 & .129 \\
\hline \multirow{3}{*}{ Simvastatin $(+)$} & Aquades (-) & $21.16667^{*}$ & 115.830 & .000 \\
\hline & $\begin{array}{c}\text { Dosis } 20,8 \mathrm{mg} / \\
\mathrm{kgBB}\end{array}$ & $3.83333^{*}$ & 115.830 & .003 \\
\hline & $\begin{array}{c}\text { Dosis 41,6 mg/ } \\
\text { kgBB }\end{array}$ & 183.333 & 115.830 & .129 \\
\hline
\end{tabular}

Berdasarkan hasil multiple comparison dengan tingkat kepercayaan 95\% yaitu pemberian aquades (kontrol negatif) pada mencit memiliki perbedaan efek/pengaruh penurunan kolesterol yang signifikan terhadap pemberian simvastatin dan ekstrak daun kelor pada dosis 20,8 mg/kgBB dan 41,6 mg/kgBB ( $<<0,05)$. Aquades tidak memiliki pengaruh terhadap penurunan kolesterol, dibandingkan dengan ketiga perlakuan lainnya. 
Pada pemberian ekstrak daun kelor dosis $20,8 \mathrm{mg} / \mathrm{kgBB}$ memiliki efek terhadap penurunan kolesterol yang mendekati efek dari pemberian ekstrak daun kelor dosis 41,6 mg/kgBB ( $>>0,05)$, namun dibandingkan dengan efek simvastatin (kontrol positif), masih signifikan perbedaannya yaitu simvastatin lebih tinggi $(\mathrm{p}<0,05)$.

Sedangkan, pemberian simvastatin sebagai kontrol positif dan pemberian ekstrak daun kelor pada dosis 41,6 mg/kgBB memiliki efek/pengaruh yang sama terhadap penurunan kolesterol dikarenakan perbedaan yang tidak signifikan $(\mathrm{p}<0,05)$.

\section{PEMBAHASAN}

Pengukuran kadar kolesterol mencit dilakukan setelah 2 minggu diadaptasikan di dalam ruangan tempat penyimpanan mencit di laboratorium penelitian. Pengukuran kadar kolesterol total darah pada awal perlakuan untuk mengetahui apakah setiap hewan uji mempunyai kadar kolesterol total normal. Namun hasil yang didapatkan mencit mengalami hiperkolestrolemik.Pengukuran selanjutnya setelah pemberian pakan tinggi lemak terjadi peningkatan kadar kolesterol pada mencit, dan pengukuran terakhir dilakukan setelah pemberian diet terapi yaitu ekstrak daun kelor, dan Simvastatin pada tiap kelompok. Pada kelompok plasebo, tidak mengalami penurunan kolesterol secara signifikan, hal ini dikarenakan aquades tidak mengandung senyawa yang berpotensi sebagai anti kolesterol dan hanya sebagai kontrol negatif.

Pada tabel 6 hasil Multiple Comparison ANOVA menunjukkan rerata kadar kolesterol darah total sebelum dan setelah pemberian pakan tinggi lemak dan diet terapi pada tiap kelompok menunjukkan perbedaan yang signifikan pada kelompok mencit dengan pemberian simvastatin dibandingkan pada kelompok aquades dan ekstrak daun kelor, meskipun pada ketiga kelompok lainnya tidak menunjukan perbedaan signifikan hanya pada jenis kolesterol pakan dan terapi.

Data yang ada pada tabel 3 pada kelompok Simvastatin apabila dibandingkan kadar reratanya, dapat dilihat bahwa terjadi penurunan kadar kolesetrol total darah mencit dengan selisih rerata 19,67 mg/dl. Penurunan terjadi karena Simvastatin bekerja menghambat 3 -hidroksis 3 - metil - glutaril - koenzim A (HMG-CoA) reduktase yang mempunyai fungsi sebagai katalis dalam pembentukan kolesterol. HMG - CoA reduktase bertanggung jawab terhadap penurunan sintesis kolesterol dan meningkatkan jumlah reseptor Low Density Lipoprotein (LDL) yang terdapat dalam membran sel hati dan jaringan ekstrahepatik, sehingga menyebabkan banyak LDL yang hilang dalam plasma. Simvastatin cenderung mengurangi jumlah trigliserida dan meningkatkan High Density Lipoprotein (HDL) kolesterol. ${ }^{8}$

Sehingga pemberian simvastatin pada kelompok mencit yang hiperkolesterolemik dapat menurunkan kadar kolesterol total darah. Hal ini sejalan dengan teori Christoper J dan Gaw A, dimana teori tersebut menyatakan bahwa simvastatin dapat menurunkan secara bermakna kadar kolesterol total darah pada mencit. 8 Berdasarkan hasil penelitian terlihat bahwa semua kelompok perlakuan yang diberi ekstrak daun kelor pada dosis 20,8 mg/kgBB, dan 41,6 mg/kgBB mengalami penurunan kadar kolesterol masing-masing sebesar 15.83 pada dosis 20,8 mg/kgBB, dan 17.83 pada dosis 41,6 mg/kgBB.Pada kelompok kontrol positif yang diberi suspensi simvastatin mengalami penurunan kadar kolesterol sebesar 19.67. 
Penurunan kadar kolesterol mencit jantan pada konsentrasi 41,6 mg/kgBB memberikan efek penurunan lebih besar dibandingkan dengan konsentrasi lainnya.Hal ini disebabkan karena jumlah kandungan kimianya yang dapat menurunkan kadar kolesterol total darah lebih besar. Karena semakin tinggi konsentrasi yang digunakan semakin banyak kandungan kimianya sehingga semakin besar pula kemampuannya menurunkan kadar kolesterol total darah. Penurunan kadar kolesterol total darah pada mencit jantan diduga disebabkan oleh senyawa-senyawa aktif dalam kadar tinggi yang terkandung dalam daun kelor.Hal ini sejalan pada penelitian sebelumnya yang membuktikan bahwa daun kelor dapat menurunkan kadar kolesterol pada hewan coba mencit karena memiliki kandungan antioksidan diantaranya vitamin C, polyphenol, flavonoid dan karoten. ${ }^{9}$

Flavonoid dapat menghambat Angiotensin converting enzyme (ACE). Diketahui ACE memegang peran dalam pembentukan angiotensin II yang merupakan salah satu penyebab hipertensi. Angiotensin II menyebabkan pembuluh darah menyempit, yang dapat menaikkan tekanan darah. ACE inhibitor menyebabkan pembuluh darah melebar sehingga darah lebih banyak mengalir ke jantung, mengakibatkan penurunan tekanan darah. ${ }^{10}$

\section{KESIMPULAN}

Pada masing-masing kelompok mencit hiperkolesterolemik yang dilakukan pemberian ekstrak daun kelor dengan dosis yang berbeda didapatkan pengaruh aquades dalam menurunkan kadar kolestrol darah pada hewan coba mencit (Mus musculus) tidak seefektif dengan pemberian simvastatin. 


\section{DAFTAR PUSTAKA}

1. Adam J. Buku Ajar Ilmu Penyakit Dalam Jilid 3. In: 5th ed. Jakarta: Balai Penerbit FK UI; 2009. p.1984-92.

2. Kee J. Pedoman Pemeriksaan Laboratorium \& Diagnostik. EGC; 2017.

3. Ganong W. Buku Ajar Fisiologi Kedokteran. Jakarta: EGC; 2008.

4. Salam AA. Uji Efektifitas Daun Lere (Ipomea Pes-Caprae (L) Roth Br.) sebagai Alternatif untuk Menurunkan Kadar Glukosa Darah Kelinci (Ocytologus Cuniculuus). Universitas Tadulako Palu; 2011.

5. Stohs SJ and Hartman MJ. Review Of The Safety and Efficacy Of Moringa Oleifera. Phyther Res. 2015;29(6):796-804.

6. Rajanandh MG, Satishkumar MN, Elango K, Suresh B. Moringa Oleifera Lam. A Herbal Medicine for Hyperlipidemia : A Pre-clinical Report. India: J.S.S University; 2012; 12(1):790-795.

7. Krisnadi, A D. Moringa Oleifera. Jawa Tengah: Kelorina.com; 2015.

8. Musculus GAM. IUCN Red List of Treatmend Species [Internet]. 2009. Available from: http://www. iucredist.org/details/13972/0

9. Agustina. Aktivitas Antioksidan dan Organoleptik Kombucha Daun Kelor dengan Lama Fermentasi dan Konsentrasi Daun Kelor yang Berbeda. Surakarta: Universitas Muhammadiyah Surakarta; 2016. pp 1-5.

10. Panjaitan R, Bintang M. Peningkatan Kandungan Kalium Urin setelah Pemberian Ekstrak Sari Buah Belimbing Manis (Averrhoa Carambola). J Vet. 2014;15(1):13-108. 